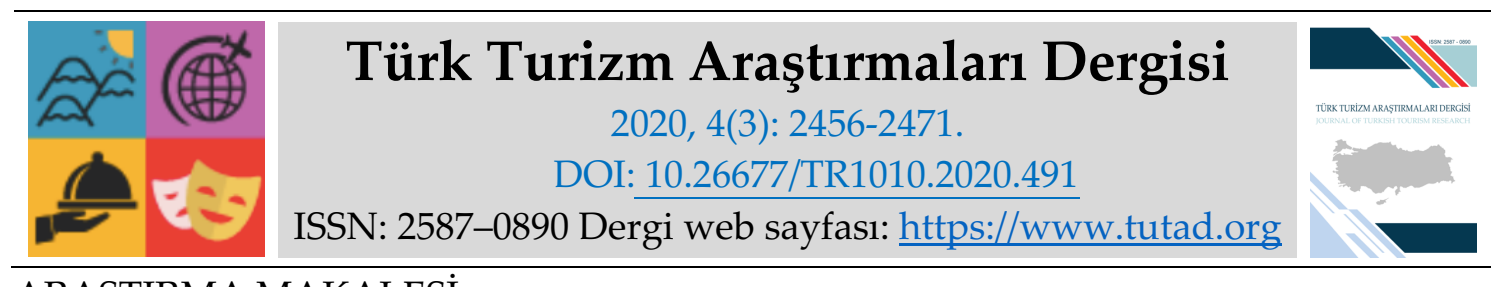

ARAȘTIRMA MAKALESI

\title{
COVID-19 Salgının Oluşturduğu Sağlık Riski Sonrasında Türk Turistlerin Tatil Beklentilerinin Belirlenmesi
}

Beste DEMİR, Yüksek Lisans Öğrencisi, Çanakkale Onsekiz Mart Üniversitesi, Turizm Fakültesi, Çanakkale, e-posta: $\underline{\text { bestedemir@anadolu.edu.tr }}$

ORCID: https://orcid.org/0000-0002-6295-1616

Dr. Öğr. Üyesi Serkan TÜRKMEN, Çanakkale Onsekiz Mart Üniversitesi, Turizm Fakültesi, Çanakkale, e-posta: serkanturkmen17@hotmail.com

ORCID: https://orcid.org/0000-0002-0921-6102

$\ddot{O} z$

Turist davranışları birçok çevresel faktörden olumsuz yönde kolayca etkilenebilmekte ve bu etkilerin başında da turistlerin sağlıklarına yönelik tehditler gelmektedir. COVID-19 tehlikesi ile turizm sektörü ve turistler açısından yaşanılan belirsizlik, en büyük sorunu oluşturmaktadır. Bu çalışmada, 2019 Aralık ayında Çin'in Wuhan kentinde başlayıp bütün dünyaya yayılan COVID-19 salgını sonrasında Türk turistlerin tatil yapmaya yönelik beklenti ve düşüncelerini tespit etmek amaçlanmaktadır. Yaşanan salgın tedbirleri kapsamında çeşitli yerel ve bölgesel kısıtlamalar yaşanması nedeni ile görüşmeler yerli turistler ile online hazırlanmış form üzerinden toplanıştır. Araştırmaya katılan katılımcı sayısı 571'dir. Araştırma sonuçlarına göre COVID-19 salgını sonrasında turistler tatil planlarını değiştirmiştir. Turistlerin önemli bir kısmı seyahat yasaklarının kalkması durumunda Temmuz-Ekim dönemi içerisinde tatil yapmayı düşündükleri ve küçük ölçekli butik tesislerde konaklama yapmak istediklerini belirtmiştir. Ayrıca turistler özellikle temizlik-hijyen ve sosyal mesafenin sağlanması hususunda turizm işletmelerinin tedbirler alması gerektiğini düşünmektedir. Bu çalışmanın bulguları turizm işletmelerinin faaliyetlerini şekillendirmelerinde katkı sağlayabilir.

Anahtar Kelimeler: COVID-19, Türk Turistler, Turist Beklentileri.

Makale Gönderme Tarihi: 16.04 .2020

Makale Kabul Tarihi: 07.07.2020

\section{Önerilen Atıf:}

Demir, B. ve Türkmen, S. (2020). COVID-19 Salgının Oluşturduğu Sağlık Riski Sonrasında Türk Turistlerin Tatil Beklentilerinin Belirlenmesi, Türk Turizm Araştırmaları Dergisi, 4(3): 2456-2471. (C) 2020 Türk Turizm Araştırmaları Dergisi. 


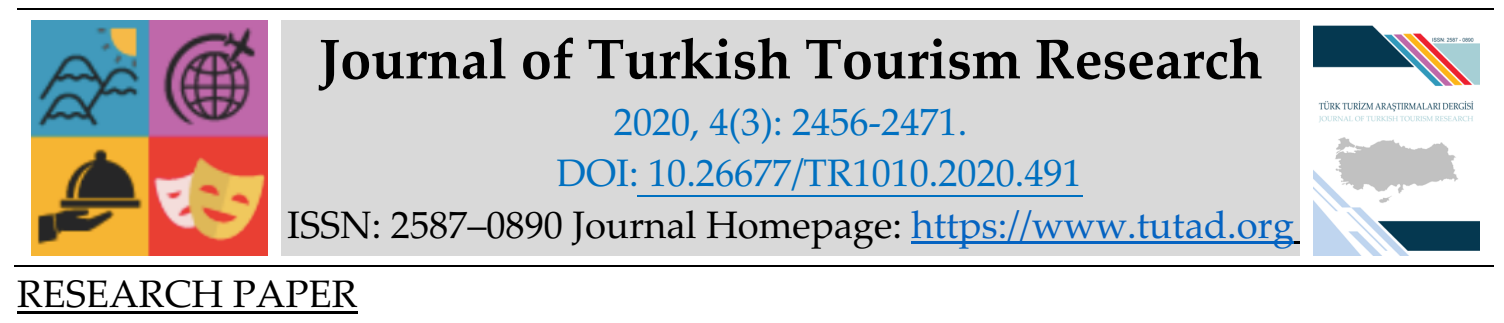

\title{
Determining the Holiday Expectations of Turkish Tourists After the Health Risk of COVID-19 Epidemic
}

Beste DEMIR, MSc. Student, Çanakkale Onsekiz Mart University, Faculty of Tourism, Çanakkale, email: bestedemir@anadolu.edu.tr ORCID: https://orcid.org/0000-0002-6295-1616

Assistant Prof. Dr. Serkan TÜRKMEN, Çanakkale Onsekiz Mart University, Faculty of Tourism, Çanakkale, e-mail: serkanturkmen17@hotmail.com ORCID: https://orcid.org/0000-0002-0921-6102

\begin{abstract}
Tourist behaviour might be easily affected from a variety of environmental factors in a negative way and the threats towards the health of tourists appear as the main one among these effects. Uncertainty caused by COVID-19 poses a major problem for the tourism sector and tourists. This study aims to identify the expectations and opinions of Turkish tourists towards going on holiday after the COVID19 pandemic that originated in the Chinese city of Wuhan and spread around the world. Due to the various local and regional restrictions in the framework of measures against the ongoing pandemic, interviews were held online through forms. 571 participants took part in the study. According to the results, tourists changed their holiday plans after the outbreak of COVID-19. A majority of the tourists stated that they consider going on holiday in a period between July-October and prefer smallscale accommodation in boutique hotels. In addition, tourists state that tourism establishments must take cleaning, hygiene and social distancing measures. The findings of this study might contribute to shape the activities of tourism establishments.
\end{abstract}

Keywords: COVID-19, Turkish Tourists, Tourist Expectations.

Received: 16.04 .2020

Accepted: 07.07.2020

Suggested Citation:

Demir, B. and Türkmen, S. (2020). Determining the Holiday Expectations of Turkish Tourists After the Health Risk of COVID-19 Epidemic, Journal of Turkish Tourism Research, 4(3): 2456-2471.

(C) 2020 Türk Turizm Araştırmaları Dergisi. 


\section{GíRIŞ}

Risk, önceden tahmin edilemeyen ve aniden ortaya çıkan olaylar olarak tanımlanmaktadır (Ünlüönen ve Çeti, 2019:109). Bu riskler çoğunlukla olumsuz sonuçlar yaratmaktadır. Olumsuz sonuçlara örnek olarak; hızlı karar verme zorluğu, zaman tasarrufu sağlamak amacıyla oluşturulan merkezi sistemli karar merkezleri, çalışanların kaygı ve gerilimlerinin artması, psikolojik ve fizyolojik çöküntüler, yönetim ve çalışanlar arasında zıtlaşmalar verilebilir. Ancak bazı durumlarda riskler olumlu sonuçlar yaratmaktadır. Örneğin yaşanan krizlerden sonra değişimler hızlanmakta ve örgütün zayıf yönleri ortaya çıktığı için bu sorunların giderilmesi sağlanmaktadır. Ayrıca geleneksel yönetimin değişip ileri zamanlar için önlemler alınması sağlanmakta, takım ruhunun gücü ortaya çıkmakta ve durumu fırsata çevirebilen işletmeler için büyümeler yaşanmaktadır (Karadeveci, 2004). Krizler çoğunlukla işletmelerde olduğu gibi sektörlerde de yaşanabilmektedir. Turizm sektöründe de yıllar boyunca farklı krizler yaşanmaktadır. Özellikle turizmin dinamik olma özelliği taşıması değişimlerden en kolay etkilenen hizmetler içinde yer almasını sağlamaktadır. Turizm sektöründe krizler; sektör kaynaklı birincil nedenli krizler olabileceği gibi sektör dışında oluşan ikincil nedenlerle de oluşabilmektedir (Göçen vd.,2011).

Turizm sektörü zaman içinde çeşitli krizler ile karşı karşıya gelmektedir. Turizm krizi; turist sayısını düşmesi sonucu yaşanan ekonomik sorunlar olarak tanımlanmaktadır (Glaesser, 2003: 6). Turizm sektöründe yaşanan krizler doğal afetler, ekonomik sorunlar, terör olayları, siyasi ve politik sorunlardır. Bölge ya da destinasyonda yaşanan salgın hastalıklar da bir kriz ortamıdır ve seyahat riski oluşturmaktadır (Ünlüönen ve Çeti, 2019). Bilinçli ya da bilinçsiz ortaya çıkabilen bu riskler her zaman turist tarafından risk algisı yaratmamaktadır.

Risk algısı temelde iki farklı şekilde oluşmaktadır. Bunlar öznel(kişisel) faktörler ve nesnel(çevresel) faktörlerdir (Kozak vd., 2007). Turizm riski algısını etkileyen öznel faktörler ise kendi içinde demografik değişkenler ve kişisel yetenekler olarak ikiye ayrılmaktadır. Demografik değişkenler yaş, cinsiyet, akademik geçmiş, sosyal statü, yaşadığı yer, eğitim düzeyi, gelir ve sosyal deneyimi içermektedir. Kişisel yetenekler ise; mizaç, kişilik, duygular, görünüm ve değerlerdir. Amir ve diğerlerinin yaptığı çalışmanın (2015) bulgularına göre; kadınların erkeklere göre risk duyarlılığ1 daha güçlüdür, eğitim seviyesi arttığında ve sosyal medya kullanımı arttığında risk algısı daha güçlüdür, bilgi kaynaklarına güven duyulduğunda risk algısı daha güçlüdür, kentte yaşayanlar kırsal da yaşayanlara göre risk algıları konusundaki farkındalığını etkilemektedir. Bu bulgulara ek olarak coğrafi ve psikolojik yakınlık gösteren turistlerin benzer duyguları paylaştıkları görülmektedir. Turizm riski algısını etkileyen nesnel faktörler ise esas olarak seyahat sırasında oluşabilecek olumsuz sonuçlara veya olumsuz etkilere işaret etmektedir.

Cui ve diğerlerinin yaptığı çalışamaya (2016) göre turistlerin algıladıkları riskler satın alma niyetini doğrudan etkilemektedir. Bunun nedeni Maslow'un ihtiyaçlar hiyerarşisinde güvenlik ihtiyacının ilk sırada yer almasıdır. Güvenlik turizm faaliyeti için gerekli olan temel taşlardandır. Bir destinasyonun ya da bölgenin güvenirliğini kaybettiğinde tekrar eski imajına dönmesi uzun bir süreç almaktadır.

Turistlerin destinasyonları ziyaret etmelerini olumsuz etkileyebilecek birçok risk bulunmaktadır ancak bu risklerin en etkililerinden biri turist sağlı̆̆ına yönelik tehditlerdir (Dolnicar, 2007). Turizm destinasyonlarının turistlerin sağlığını tehdit edecek unsurları ortadan kaldırması tercih edilirliği artırabilecek etkenler içinde yer almaktadır (Li vd., 2017). Sağlık tehdidinin yaşandığı yerlerde kriz çıkması muhtemeldir. Bu nedenle yaşanacak krizlere karşı her sektör ve meslek grubunun hazırlıklı olması oldukça önemlidir. 


\section{COVID-19 ve TURIZM}

Turizm gelirleri ekonomik büyümeyi önemli bir şekilde etkilemektedir. Farklı destinasyonlarda yapılan çalışmalarda turizm gelirleri ile ekonomik büyüme arasında pozitif yönlü bir ilişki olduğu sonucuna ulaşılmıştır (Ivanov ve Webster, 2007; Mayer vd., 2010; Pratt, 2015; Zurub vd., 2015; Gulzar vd., 2019; Fendoğlu ve Gökçe, 2019). Turizm gelirleri ülkelerine en önemli gelir kaynakları içinde yer almaktadır. 2019 verilerine göre; Türkiye turizm gelirlerini 34,5 milyar dolara çıkarmayı başarmıştır (www.tursab.org.tr). Turizm faaliyetleri önemli bir döviz getirisi sağlarken aynı zamanda önemli bir istihdam gücüde yaratmaktadır. Bu nedenle COVID-19 nedeniyle ertelenen ya da iptal edilen turizm faaliyetlerinin ilerleyen günlerde ekonomik sorunları da beraberinde getirmesi kaçınılmazdır.

COVID-19 olarak adlandırılan salgın hastalık ilk kez 2019 yılının aralık ayında, Çin'in Wuhan şehrinde görülmeye başlanan ve son yılların en büyügü kabul edilen krizlerdendir. Bulaşıcı ve salgın olan hastalıklar epidemi olarak tanımlanmaktadır. Epidemik, bir salgın hastalığın o toplumda beklenenden fazla görülmesi durumudur. Koronavirüsü olarak da adlandırılan COVID-19, 11 Mart 2020 tarihinde ise Dünya Sağlık Örgütü tarafından pandemi olarak ilan edilmiştir. Pandemi ise bir epideminin birçok insan, ülke ve kıtayı etkiletmesi olarak tanımlanmaktadır. COVID-19 mutasyona uğramış ve doğal bir yolla meydana gelmiş bir virüstür. Bu virüsün farkı bulaşma gücünün fazla olmasıdır bu nedenle kontrol altına almak diğer virüslere göre daha zordur (Aslan, 2020). Virüsün sahip olduğu bu özellikler nedeniyle salgın kısa sürede dünyanın birçok yerine ulaşmıştır.

Tarih boyunca çeşitli hastalıklar yaşanmıştır. Domuz gribi, ebola, kuş gribi ve SARS bunlardan sadece bazılarıdır. İlgili literatür incelemesi yapıldığında bu hastalıkların turizm üzerinde etkilerinin olumsuz sonuçlar yarattığı açık bir şekilde görünmektedir. Hastalığın yaşandığı bölgelerde turist sayılarında belirli bir azalma meydana gelmektedir (Ünlüönen ve Çeti, 2019). Ancak içinde bulunduğumuz salgın hastalık farklıdır. Bu hasatlığın farklı olmasının temel nedenlerinden biri çıkış noktasının belirlenememesi, tedavilere ve aşı çalışmalarına cevap vermemesidir. Bulaşma gücü ise önceki salgın hastalıklara göre oldukça güçlüdür. Üç kişinin başka üç kişiye bulaştırması sonucunda hastalık etkeni 59 bin kişiye kadar çıkmaktadır. 15 Mayıs tarihinde güncellenen verilere göre; 4 milyon 307 bin onaylanmış vaka, 295.101 bin onaylanmış ölüm, hastalığın görüldüğü 216 ülke ya da bölge bulunmaktadır (www.who.int). Çin'in Wuhan kentinde çıkan hastalığın zaman geçtikçe merkez üssünü değiştirdiği görülmektedir. Önce İtalya ve Avrupa'dan raporlanan sayılar rekor artışlar göstermiştir. Daha sonra Amerika Birleşik Devletleri merkez üssü haline gelmiştir. Hastalığın çıkış noktası kabul edilen Çin'de ise Çin Ulusal Sağlık Komisyonu tarafından yapılan 20 Mart tarihindeki açılamaya göre ülkede iki gündür yeni hasta tespit edilmediği duyurulmuştur. Yaşanan gelişmeler sonucunda Çin 8 Nisan'dan itibaren normal hayata geçiş adımlarına başlamış ve sokağa çıkma yasağı kaldırılmıştır (www.hurriyet.com.tr).

Virüsün ülkeler hatta kıtalar arasında bu kadar hızlı yayılmasının ana nedenlerinden biri ise gelişen teknoloji sayesinde insanların bir yerden bir yere kolay seyahat etme firsatıdır. Yapılan bilimsel araştırmalar sonucunda bu hipotez doğrulanmıştır (Wilson ve Chen, 2020). Dünya Sağlık Örgütü çeşitli alanlarda yapılan araştırmalardan sonra birçok önlem ve kısıtlama getirmiştir. Getirilen önlemlerin çoğu doğrudan ya da dolaylı olarak turizm faaliyetleri ile ilgilidir. Alınan ilk önlemler genellikle Çin ile olan uçuşları durdurmak ya da kısıtlamak ile başlamaktadır. 11 Mart 2020 tarihinde Dünya Sağlık Örgütü'nün COVID-19'u pandemi ilan etmesinden sonra alınan önlemler daha da katılaşmaya başlamaktadır. Dünyada alınan başlıca önlem ve kısıtlamalar; 15 Mart tarihinde Avrupa birliğinde $\mathrm{ABD}^{\prime}$ ye gelen zorunlu olmayan bütün uçuşların durdurulması, 16 Mart Avrupa Birliği'nin Schengen bölgesi dışında kalan ülkelere sınırlarının kapatılması, İspanya'da tüm ülkenin 
karantinaya alınması, İtalya' da tüm ülkenin karantinaya alınması, Fransa'da 17 Mart 2020 tarihinden itibaren kısmi sokağa çıkma yasağı uygulamasıdır. Alınan bu önlemler ile uluslararası turizm faaliyetleri durdurulmuş çekim merkezi birçok destinasyon ve müzeler geçici olarak faaliyet dışı bırakılmıştır.

Türkiye' de ise 11 Mart tarihinde görülen ilk vakadan sonra hızla çeşitli kısıtlamalar getirilmiştir. 13 Mart tarihinde uzak doğu ülkeleri ağırlıklı olarak uçuşlar durdurulmaya başlanmıştır. Uçuş yasaklarından kıssa bir süre sonra kara ulaşımında da tedbirler alınmış komşu ülkelerden Azerbaycan ve Gürcistan ile sınırlar karşılıklı olarak kapatılmıştır. 17 Mart tarihinde ise Avrupa ülkelerinin de içinde olduğu 9 ülkeye daha uçuş kısıtlaması getirilmiştir. 21 Mart tarihinde ülke içindeki şehirler arası seyahat valiliklerin iznine bağlanmıştır. Seyahat kısıtlamalarından sonra tedbirler daha da genişletilmiş ve 11 Nisan itibariyle 30 büyük şehir ve Zonguldak ili için geçici sokağa çıkma yasağı ilan edilmiştir (www.bbc.com).

Alınan tedbir ve kısıtlamalardan sonra yaşanan seyahat iptalleri sonucu hava yolu şirketleri ve bütün turizm paydaşları olumsuz etkilenmektedir. Airports Council Intertanional'ın sunduğu rapora göre; 2020 yılının ilk çeyreğinde dünya genelinde havayolu yolcu sayıları \%12 azalma göstermektedir (ACI, 2020:1-25). Yine yapılan bir başka araştırmaya göre salgının kısa bir sürede kontrol altına alınamaması sonucu havayolu işletmelerinde her ay yaklaşık 35 milyar dolar zarar yaşanacağını ön görmektedir (IATA, 2020). Bu zararların sadece havayolu şirketleri baz alınarak hazırlanması ve diğer turizm paydaşlarının da en az bu miktarlar kadar zarara uğrayacağı düşünüldüğünde yaşanılan krizin önemi daha da iyi kavranmaktadır.

COVID-19 salgını tespit edildiği ilk günden itibaren dünyanın ilgi odağında yer almaktadır. Etkileri bütün dünyada ve her sektörde görülmektedir. Ancak krizin çok ani olması ve hızla yayılması bütün dünya için beklenmedik bir durumdur. Bu nedenle COVID-19 konulu birçok bilimsel araştırma yapılmaktadır. Çalışmalar öncelikle sağlık alanında yapılmaya başlanmış ve virüsün özellikleri tespit edilerek alınacak önlemler oluşturulmaya çalışılmıştır. Turizm alanında yapılan çalışmalar ise kisitlidır.

Atay (2020) tarafından yapılan çalışmada COVID-19 salgının dünyadan etkileri incelenmekte ve olası ön görüler üzerinde durulmaktadır. Yaşanan krizlerden her turizm paydaşının olumsuz etkileneceği belirtilerek bazı öneriler sunulmaktadır. Özellikle her paydaş için teknolojinin önemi üzerinde durulmaktadır. Çalışmada akıllı şehir ve akıllı destinasyon uygulamalarına geçilmesi önerilmektedir.

Acar (2020) tarafından yapılan çalışmada 31 Aralık 201-10 Mart 2020 tarihleri arasında dünyada alınan tedbir ve kısıtlamalar incelenmektedir. Çalışmada Dünya Sağlık Örgütüne ait resmi internet sitesinden alınan veriler doküman analizi yöntemi ile incelenmektedir. Araştırmanın bulgularında; COVID-19 salgınının ülkelerin ekonomilerine uzun süre zarar yaratacağına ve turizm sektörünün de bu zararlardan doğrudan etkileneceğine ulaşılmaktadır.

İbiş (2020) tarafından yapılan çalışmada COVID-19 salgının seyahat acentaları üzerinde yarattığı etkiler araştırılmaktadır. Araştırmada 11 acenta çalışanı ile görüşme gerçekleştirilmiştir. Çalışmanın bulgularında; seyahat acentalarının salgından özellikle ekonomik olarak büyük ölçüde etkilendiği ancak destekleri yeterli bulmadıkları bilgisine ulaşılmaktadır.

Grössling ve arkadaşları (2020) tarafından yapılan çalışmada önceki yıllarda yaşanan salgın hastalıklar ve COVID-19 salgını karşılaştırılmaktadır. Çalışmada COVID-19'un sonuçları ya da 
etkilerinin hala belirsiz olduğu bu nedenle daha çok bilimsel çalışmaya ihtiyaç olduğu belirtilmiştir. Buna ek olarak salgın sonrasında turizm sektöründe rekabet ortamının artacağı ve fiyatların düşeceği öngörülmektedir.

Hoque ve arkadaşları (2020) tarafından yapılan çalışmada COVID-19'un Çin turizm ekonomisine etkisi araştırılmaktadır. Araştırma yöntemi olarak ikincil veriler kullanılmıştır. Araştırma bulgularında; Çin'de ortaya çıkan bu salgının bütün dünyada önemli etkilere sahip olduğu savunulmaktadır. Bu salgın dünya genelinde Çin vatandaşlarına karşı korkunun ortaya çıkmasını sağlamıştır. Çin'e yapılması planlanan uçuş ve tatiller hızla iptal edilmektedir. Salgının Çin turizm sektöründe uzun yıllar etki yaratacağı öngörülmektedir.

Yang ve arkadaşları (2020) tarafından yapılan çalışma krizlerin turizm çalışanları üzerine olumsuz etkiler yarattığını ve birçoğunun işsiz kaldığını göstermektedir. Çalışmanın önerisi salgın hastalık için kullanılabilecek dinamik stokastik genel denge modeli ortaya koymaktır.

Ünlüönen ve Çeti (2020) tarafından yapılan çalışmada salgın hastalıkların turizm sektörü üzerine etkileri incelenmektedir. Çalışmada ayak ve göz hastalığı, SARS, kuş gribi, domuz gribi ve ebola salgınları incelenmektedir. Salgınların etkisi özellikle turist sayıları üzerinde görülmektedir. Çalışmanın bulgularına bakıldığında salgın yaşanan bölgede, ertesi yıl turist sayısında düşüşler olduğu görülmektedir.

İlgili literatür incelendiğinde, salgının çeşitli sektör ya da paydaşlar üzerinde etkileri saptanmaya çalışılmaktadır. Turizm sektörü üzerindeki etkisini ciddi bir şekilde hissettiren COVID-19 salgının turist davranışları üzerinde etkilerini inceleyen çalışmaların sayısı önümüzdeki günlerde artacağı tahmin edilse de henüz ulaşılabilen literatürde Türk turistler üzerinde yapılan bir çalışmaya rastlanamamıştır. Turizm sektörünün bu krizle mücadelesinde turistlerin konu ile düşüncelerinin araştırılması birçok belirsizliği barındıran mevcut durumda doğru ve güvenilir öngörülerde bulunmak ve önlemler açısından son derece önemlidir.

Bu çalışmada, turizm faaliyetlerinin öznesini oluşturan turistlerin salgın hastalık ile ilgili düşünceleri ve salgın sonunda turizm faaliyetlerine olan bakış açıları ve beklentileri tespit edilmeye çalışılmaktadır. Çalışma bulgularının, turizm sektörü içerisinde yer alan aktörlerin gerekli önlemleri almasına ve krizi az hasarla atlatmasına yardımcı olması amaçlanmaktadır.

\section{YÖNTEM}

Bu çalışmanın amacı COVID-19 salgını sonrasında Türk turistlerin tatil yapmaya yönelik bakış açıları ve beklentilerinin ortaya çıkarılmasıdır. Bu amaç doğrultusunda aşağıdaki araştırma sorularına yanıt aranmıştır,

1. COVID-salgını turistlerin çalışma hayatlarını etkiledi mi?

2. COVID- salgını 19 turistlerin tatil planını etkiledi mi?

3. 2020 yaz sezonunda tatil yapmayı düşünüyorlar mı?

Devletin izin vermesi durumunda;

4. Turistler ne zaman tatil yapmayı düşünüyorlar?

5. Tatillerinde hangi konaklama türünü tercih ederler?

6. Hangi bölgede tatil yapmak isterler?

7. Rehberli bir tura katılmak isterler mi? 
8. Turistlerin tatile çıkma isteklerindeki amaçlar neler?

9. COVID-19 salgını sonrasında turizm işletmelerinin almasını istedikleri tedbirler nelerdir?

Araştırma sorularına yönelik ihtiyaç duyulan verileri elde etmek için anket tekniği kullanılmıştır. Katılımcılar 9 açı uçlu, 7 çoktan seçmeli soru yöneltilmiştir. İçerik analizi seçici, sınıflandırıcı ve nicelleştirici bir yöntemdir ve yazılı metinlerin incelenmesinde kullanılabilir (Gökçe, 2006: 19). Açık uçlu sorulara verilen yanıtlar, içerik analizi ile incelenmiştir. Hazırlanan çevrimiçi anket kolayda örnekleme yöntemiyle \#tatil etiketiyle sosyal medyada paylaşım yapan 1240 Türk turiste mesaj olarak iletilmiş ve gönderilen mesajda turizm işletmelerinde tatil yaptığını bildikleri tanıdıklarıyla paylaşabilecekleri de ifade edilmiştir. Daha önce bir turizm işletmesinde tatil yapmayan kişilerin ankete ulaşmasını engellemek için doğrudan mesaj yoluyla anketler turistlere ulaştırılmaya çalışılmıştır. 27 Nisan- 4 Mayıs 2020 tarihleri arasında 571 turistin anketleri doldurması sağlanmıştır. Araştırma örneklemi 571 Türk turistten oluşmaktadır.

\section{BULGULAR}

Araştırma yapılan grubun cinsiyet, medeni durum, aylık gelir, yaş aralıkları, meslekleri ve ikamet ettikleri illere ilişki bilgiler Tablo 1'de yer almaktadır.

Tablo:1 Demografik Bulgular

\begin{tabular}{lll|lll}
\hline Cinsiyet & $\mathbf{N}$ & $\mathbf{\%}$ & Medeni Durum & $\mathbf{N}$ & $\mathbf{\%}$ \\
Kadın & 284 & 49,7 & Evli & 220 & 38,5 \\
Erkek & 287 & 50,3 & Bekar & 351 & 61,5 \\
\hline Gelir & $\mathbf{N}$ & $\mathbf{\%}$ & Yaş & $\mathbf{N}$ & $\mathbf{\%}$ \\
2499 TL ve altı & 138 & 24,2 & $18-24$ yaş & 177 & 31 \\
2500-4999 TL & 174 & 30,5 & $25-34$ yaş & 223 & 39,1 \\
5000-7499 TL & 112 & 19,6 & $35-44$ yaş & 110 & 19,2 \\
7500-9999 TL & 18 & 3,2 & $45-54$ yaş & 31 & 5,4 \\
10000 TL+ & 38 & 6,7 & $55+$ yaş & 30 & 5,3 \\
Belirtmek & & & & & \\
istemeyen & 36 & 6,3 & & & \\
\hline İkamet İli & $\mathbf{N}$ & $\mathbf{\%}$ & Meslek & $\mathbf{N}$ & $\mathbf{\%}$ \\
İstanbul & 152 & 26,6 & İşçi & 137 & 24,0 \\
İzmir & 74 & 13,0 & Serbest meslek & 87 & 15,2 \\
Ankara & 67 & 11,7 & Kamu personeli & 71 & 12,4 \\
Bursa & 54 & 9,5 & Esnaf & 51 & 8,9 \\
Antalya & 27 & 4,7 & Yönetici & 45 & 7,9 \\
Balıkesir & 24 & 4,2 & İşletmeci & 32 & 5,6 \\
Aydın & 23 & 4,0 & Öğretmen & 35 & 6,1 \\
Çanakkale & 21 & 3,7 & Öğrenci & 39 & 6,8 \\
Denizli & 16 & 2,8 & Emekli & 19 & 3,3 \\
Kırklareli & 15 & 2,6 & Akademisyen & 18 & 3,2 \\
Diğer İller (34) & 98 & 17,2 & Çalışmayan & 37 & 6,5 \\
\hline
\end{tabular}


Araştırmaya katılan Türk turistlerin cinsiyete göre dağılımları birbirine çok yakındır. Araştırmaya dahil edilen katılımcıların yaklaşık \%54'ünün 2499-4999 TL aralığında aylık gelire sahip olduğu ve katılımcıların yaklaşık \%70'inin de 18-34 yaş aralığında olduğu tespit edilmiştir. Katılımcıların meslek grupları ele alındığında yaklaşık \%24'ünün işçi ve \%15'ininde serbest çalışan (avukat, mimar, mühendis vb.) grubunda yer aldığı tespit edilmiştir. Katılımcıların \%51'inin üç büyük ilde (İstanbul, Ankara ve İzmir) ikamet ettiği görülmektedir.

Turistlerin COVID-19 sonrasında çalışma durumları ve tatil yapmaya yönelik düşüncelerini tespit etmek için sorulan sorulara yönelik verdikleri yanıtlar sonrasında elde edilen bilgiler Tablo 2' de yer almaktadır.

Tablo 2: Turistlerin Pandemi Algısı ve Tatil Düşünceleri

\begin{tabular}{|c|c|c|c|c|c|}
\hline Salgında Çalışma Durumu & $\mathbf{N}$ & $\%$ & Tesislerde Tatil Yapma & $\mathbf{N}$ & $\%$ \\
\hline Ücretsiz izne ayrılan & 74 & 13 & Çıkmayan & 26 & 4,6 \\
\hline Yıllık izne ayrilan & 13 & 2,3 & 2015 yılı ve öncesinde & 17 & 3 \\
\hline Çalışmaya devam eden & 79 & 13,8 & 2016 yılında & 11 & 1,9 \\
\hline Evet, esnek çalışıyorum & 159 & 27,8 & 2017 yılında & 16 & 2,8 \\
\hline Çalışamıyorum & 190 & 33,3 & 2018 yılında & 74 & 13 \\
\hline Çalışmayan & 56 & 9,8 & 2019 yılında & 364 & 63,7 \\
\hline Kovid 19'un Tatil Planına Etkisi & $\mathbf{N}$ & $\%$ & 2020 yılı içinde & 63 & 11 \\
\hline Evet, erteledim. & 131 & 22,9 & Haziran ayından & $\mathbf{N}$ & $\%$ \\
\hline Evet, iptal ettim. & 97 & 17 & $\begin{array}{l}\text { itibaren otellerde } \\
\text { sertifikalı sistemin } \\
\text { başlaması durumunda }\end{array}$ & & \\
\hline Hayır, değişiklik yapmadım. & 34 & 6 & $\begin{array}{l}\text { Tatile çıkmayı } \\
\text { düşünürüm }\end{array}$ & 182 & 31,9 \\
\hline Hayır, planım yoktu. & 309 & 54,1 & $\begin{array}{l}\text { Tatile çıkmayı } \\
\text { düşünmem }\end{array}$ & 389 & 68,1 \\
\hline Tatil yapmayı düşünülen zaman & $\mathbf{N}$ & $\%$ & $\begin{array}{l}\text { Covid -19 tehlikesinin } \\
\text { geçmesi }\end{array}$ & $\mathbf{N}$ & $\%$ \\
\hline Pandemi bitince & 39 & 6,8 & 1-2 ay sürer & 163 & 28,5 \\
\hline En az 1 yil sonra & 143 & 25 & 3-4 ay sürer & 107 & 18,7 \\
\hline Eylül-Ekim ayı içinde & 123 & 21,5 & 5-6 ay sürer & 54 & 9,5 \\
\hline Ağustos ayında & 166 & 29,1 & 1yıl sürer & 153 & 26,8 \\
\hline Temmuz ayında & 77 & 13,5 & $2+$ y1l sürer & 53 & 9,3 \\
\hline Haziran ayında & 23 & 4,1 & Hiç bitmeyecek & 41 & 7,2 \\
\hline $\begin{array}{l}\text { İmkan olursa nerede tatil } \\
\text { yapılmak istenen yer }\end{array}$ & $\mathbf{N}$ & $\%$ & $\begin{array}{l}\text { Bu süreçte hangi tür } \\
\text { konaklamayı tercih } \\
\text { edersiniz }\end{array}$ & $\mathbf{N}$ & $\%$ \\
\hline Yurtiçi herhangi bir yer & 51 & 8,9 & Butik tesisler & 237 & 41,5 \\
\hline Yurt dişı & 41 & 7,2 & Büyük (otel-tatil köyü) & 161 & 28,2 \\
\hline Ege Bölgesi & 215 & 37,7 & Çadır-Kamp & 118 & 20,7 \\
\hline Akdeniz Bölgesi & 101 & 17,7 & Yazlık ev & 37 & 6,5 \\
\hline Marmara Bölgesi & 86 & 15,1 & Diğer (Karavan, apart vb) & 18 & 3,1 \\
\hline Karadeniz Bölgesi & 46 & 8,1 & $\begin{array}{l}\text { Rehberli Tura katılma } \\
\text { İsteği }\end{array}$ & $\mathbf{N}$ & $\%$ \\
\hline Güney Doğu & 16 & 2,7 & Evet & 200 & 35 \\
\hline İç Anadolu & 15 & 2,6 & Hayır & 371 & 65 \\
\hline
\end{tabular}


Tablo 2 incelendiğinde turistlerin pandemi sonrasında yaklaşı \%33'ü çalışamadığını ve yaklaşık \%28'i de esnek çalıştığını belirtmiştir. Katılımcılardan pandeminin ne zaman biteceğini ön görmeleri istendiğinde ise \%28'i 1-2 ay içinde biteceğini düşünürken yaklaşık \%27'lik azımsanamayacak bir kısmı ise sürecin en 1 yıl daha devam edeceğini ifade etmiştir.

Turistlerin yaklaşık \%10'u da normal zamanlarda da çalışmadığını ifade etmiştir. Turistlerin yaklaşık \%64'ü 2019 yılında ve yaklaşık \%11'i de 2020 yılında bir turizm işletmesinden (konaklama) yararlandıklarını ifade etmiştir. Turistlere turizm işletmelerinin haziran ayında sertifikalı bir şekilde faaliyete geçme durumlarında tatil yapmayı düşünür müsünüz diye sorulduğunda yaklaşı \%68'i düşünmediğini ifade etmiştir. Turistlerin yaklaşık \%23'ü tatil planını ertelediğini ve \%17'si ise tatil planlarını iptal etmişlerdir.

Devletin tekrar seyahat kısıtlamalarını kaldırması durumunda tatile çıkmayı düşündükleri zaman ele alındığında yaklaşık \%29'u ağustos ayı içerisinde ve yaklaşık \%23'ü de Eylül-Ekim ayları içerisinde tatil yapmayı düşündüklerini ifade etmişlerdir. Turistlerin $\% 25$ 'i ise en az bir yıl sonra tatil yapacaklarını ifade etmişlerdir. Turistler bu süreçte eğer tatil yapsalardı hangi tür konaklamayı tercih edecekleri sorulmuş, yaklaşık \%42'si butik tesislerde, yaklaşık \%21'i çadır-kamp şeklinde ve \%28'i de büyük tesislerde (otel-tatil köyü) tatil yapmayı düşündüklerini belirtmişlerdir.

Analizlere göre imkan bulmaları durumunda katılımcıların yaklaşık \%55’lik kısmı Ege ve Akdeniz bölgesini tercih edeceklerini ifade etmişlerdir. Sadece yaklaşık \%7'si yurtdışında tatil yapmayı düşünmektedir. Turistlerden sadece \%35'i rehberli tura katılmak istediğini ifade etmiştir. Turistlerin ilk fırsatta hangi amaçla tatil yapmak istediklerine ilişki sorulan açık uçlu soruya ilişkin yanıtlar içerik analizi ile incelenmesi ve Tablo 3'te gösterilmiştir.

Tablo 3: Turistlerin İlk Fırsatta Tatile Çıkma Amaçları

\begin{tabular}{|c|c|c|c|}
\hline \multirow{17}{*}{$\begin{array}{l}\text { Turistlerin ilk fırsatta tatile çıkma } \\
\text { amaçları }(796)^{*}\end{array}$} & & $\mathrm{~N}$ & $\%^{* *}$ \\
\hline & Rahatlama ve Dinlenme & 448 & 78,5 \\
\hline & o Psikolojik yorgunluk (64) & & \\
\hline & o Rahatlama (75) & & \\
\hline & o Dinlenme (158) & & \\
\hline & o Stres atmak (42) & & \\
\hline & o Yorgunluk atmak (28) & & \\
\hline & o Yenilenmek (33) & & \\
\hline & o Rutinden uzaklaşmak (48) & & \\
\hline & Deniz, kum, güneş & 76 & 13,3 \\
\hline & Yeni yerler gezip görmek & 71 & 12,4 \\
\hline & Eğlenmek & 67 & 11,7 \\
\hline & Aile ve arkadaşlarla keyifli vakit geçirmek & 62 & 10,9 \\
\hline & Doğada vakit geçirmek & 37 & 6,5 \\
\hline & Tarih ve Kültür & 18 & 3,2 \\
\hline & Çeşitli aktiviteler (yamaç paraşütü, bisiklet) & 13 & 2,2 \\
\hline & Balay1 & 4 & 0,7 \\
\hline
\end{tabular}

*Bazı turistlerin birden fazla tatile çıkma amacı olduğu için katılımcı sayısı 571'den fazladır.

${ }^{* *}$ Katılımcı sayısına göre oranlama yapılmıştır. 
Katılımcıların tatile çıkma ihtiyaçları altına yatan sebepleri tespit etmeye yönelik verilen cevaplar incelendiğinde, yaklaşı \%79'unun rahatlama ve dinlenme amaçlı tatil yapmak istedikleri tespit edilmiştir. Katılımcıların yaklaşık \%13'ü deniz, kum, güneş amacıyla, yaklaşık \%12'si yeni yerler görmek amacıyla, \%11'i aile ve arkadaşlarıyla keyifli zaman geçirmek ve yaklaşık \%12'si eğlenmek için tatil yapmak istediklerini ifade etmişlerdir. Bunların yanında yaklaşık \%7'si de doğada vakit geçirmek istediğini belirtmiştir.

Katılımcıların açık uçlu olarak sorulan bu soruya verdikleri yanıtlardan bazıları şunlardır;

- "Esnek çalışma saatlerinde çok bunaldım ve bir yandan enflasyon yüzünden ekonomik olarak çok bunaldım. Zihnimi boşaltmak ve rahatlamak için tatil yapmak istiyorum.",

- "İ̧s hayatının yoğunluğundan uzaklaşmak ve karantina sürecinin etkisinden kurtulmak için tatil yapmak istiyorum.",

- Inşallah kısa sürede her şey normale döner. Çünkü tek sevdiğim ve tatil yapmak istediğim mevsim yaz. Denizi ve güneşi özledim.",

- "Karantinada psikolojim bozuldu doğaya çıkmayı ve gezmeyi özledim.",

- "Yoğun iş temposundan oluşan yorgunluğu atmak ailemle keyifli vakit geçirmek istiyorum",

- "Eğlenmek istiyorum, güzel ve stresten uzak, koşuşturmadan uzak kafa dinleyeceğim bir yere gitmek istiyorum."

Turistlerin yaşanan bu durum sonrasında turizm işletmelerinden almasını istedikleri tedbirlere yönelik bulgular Tablo 4'te verilmiştir.

Katılımcıların yaklaşık \%84'ü temizlik ve hijyen konusunda turizm işletmelerinden beklentileri olduklarını ifade etmişlerdir. Katılımcıların yaklaşık \%22'si işletmelerden turizm işletmelerinde sosyal mesafe planlaması yapmaların beklerken yaklaşı $\% 10^{\prime} \mathrm{u}$ da kapasitenin düzenlenmesini istemiştir. Ayrıca katılımcıların yaklaşık \%16,3'ü tedbirlerin COVID-19 tehlikesine engel olamayacağ1 görüşündedir. Bu görüşün altında önlemlerin bulaşıcılığa engel olunamayacağ1 ve tedbirlere uyulamayacağı gibi görüşler yer almaktadır.

Kişilerin turizm işletmelerinden almasını istediği tedbirlere ilişkin katılımcı ifadelerinden bazıları şunlardır;

- "Bilim kurulunun söylediği ve diğer ülkelerde uygulanan standartlar sağlanmalı.",

- "Covid-19'a yönelik sertifika sistemleri oluşturulmalı.",

- "Havuzlarm kapalı olması, restoranların ve ortak alanlarm kapasitesinin yarısı kadar misafir kabul edilmesi ve her konaklamadan sonra odalarda dezenfeksiyon yapılması gerekir.",

- “Odaların ve kapalı alanların dezenfeksiyonu sağlanmal, odaların bizden önce kalan kişilerden sonra en az 1 gün boyunca boş bırakılması gerekir. Nevresimler ve havlular gibi ürünler yıkanabilecek ne varsa ultra sicakta yıkanmal. Her ye belirli aralıklarla dezenfekte edilmeli.",

- Masalar birbirine mesafeli olsun. Müşteri tarafindan kullanilan her ürün -en azından şu pandemi tamamen sonlanana kadar- diğer müşteri kullanmadan dezenfekte edilsin. İşletmelerde sosyal mesafenin să̆lanabileceği şekilde tam kapasite ile çalışılmaması gerekir.",

- "Salgın mevcut kontrol edilemez haliyle devam ederse hangi önlem alınırsa alınsin hastalı̆̆ı özelliği ve mekânların özellikleri ile önlemlere dikkat etmeyecek insanların da her zaman var olduğu bir arada 
düşünülünce sertifikalı sistemler dahi olsa işletmelerin hizmet vermeye başlamaması gerekir. Çünkü önlem almanın bulaşıcılı̆̆a engel olamayacağın düşünüyorum.",

- "Virüsün tamamen yok edildiğinden emin olana kadar dokunulacak dokunulmayacak her yüzeyin hijyenik olmasını, gıdaların özenle temizlenmesini, çalışanların ve misafirlerin toplu bulunulan yerlerde maske kullanmasin isterim."

Tablo 4: Turizm İşletmelerinin Alması İstenen Tedbirler

\begin{tabular}{|c|c|c|c|}
\hline \multirow{21}{*}{$\begin{array}{l}\text { İşletmelerin alması gereken } \\
\text { tedbirler }(877)^{*}\end{array}$} & & $\mathbf{N}$ & $\% * *$ \\
\hline & Temizlik ve Hijyen & 481 & $84,2 \%$ \\
\hline & Hijyen Tedbirleri (226) & & \\
\hline & Temizlik (112) & & \\
\hline & Dezenfeksiyon (81) & & \\
\hline & Eldiven ve Maske Kullanımı (13) & & \\
\hline & Ortak Tuvalet vb. Temizliği (18) & & \\
\hline & Havalandırmaların Temizliği (7) & & \\
\hline & Odalar için Çeşitli Tedbirler (24) & & \\
\hline & İşletmelerde Sosyal Mesafenin Planlanması & 123 & 21,5 \\
\hline & İşletme Kapasitelerinin Düzenlenmesi & 58 & 10,2 \\
\hline & Yiyecek ve İçecek tedbirleri & 51 & 8,9 \\
\hline & Sağlık Kontrollerinin Yapılması & 21 & 3,7 \\
\hline & Sertifika ve prosedürlerin kullanımı & 16 & 2,8 \\
\hline & Yabanc1 Turist Kabul Edilmemesi & 18 & 3,2 \\
\hline & Ortak havuzların kullanılmaması & 11 & 1,9 \\
\hline & Tek kullanımlık ürün kullanımı & 5 & 0,9 \\
\hline & Tedbirlerin Önemi Yok & 93 & 16,3 \\
\hline & Önlemler İşe Yaramaz (30) & & \\
\hline & Önlemler Uygulanmaz (15) & & \\
\hline & Teknik Olarak Önlenemez (48) & & \\
\hline
\end{tabular}

"Bazı turistlerin birden fazla tatile çıkma amacı olduğu için katılımcı sayısı 571'den fazladır.

${ }^{* *}$ Katılımcı sayısına göre oranlama yapılmıştır.

\section{SONUÇ ve ÖNERILLER}

Turizm sektörünün dolayısıyla turist davranışlarının birçok faktörden etkilenebilen esnek bir yapısı vardır (Lohmann, 2004). Turistlerin sağlıklarına yönelik algıladıkları tehdit ve riskler, turistlerin tatil yapma niyetlerini olumsuz etkileyen ve destinasyon tercihinde karar vermede etkili olan unsurlar arasında yer almaktadır (Jonas vd., 2011). Bu çalışmada COVID-19 salgını ve bulaşma tehdidi sonrasında Türk turistlerin tatil yapma düşünceleri ve beklentileri tespit edilmeye çalışılmıştır.

Küresel boyuttaki bulaşıı hastalıklar ülke ekonomilerini ve çalışma hayatını olumsuz etkilemektedir (McKibbin ve Fernando, 2020). Bu çalışmanın bulgularında COVID-19'un Türk turistlerin çalışma biçimlerini ve çalışma durumlarını bütün dünyada olduğu gibi olumsuz etkilediği tespit edilmiştir. 
Ancak COVID-19'un yarattığı tehlikenin geçmesine yönelik beklentiler ele alındığında katılımcıların \%29'u 1-2 ay ve \%19'u 3-4 ay içinde bu tehlikenin biteceğini savunurken önemli bir kısmı da (\%43) bir yıldan fazla süreceğini ifade etmektedir.

Türk turistler içinde tatil planı olanların önemli bir kısmının planlarını iptal ettiği veya ertelediği sonucuna ulaşılmıştır. Pandemi ile ilgili tedavi, aşı, tehlikesi vb. sebeplerden dolayı belirsiz durumun olması planların iptal ve ertelenmesinde etkili olduğu aşikardır. Ayrıca turizm işletmelerinin COVID-19 ile ilgili oluşturulacak sertifikaya sahip bile olunsa şu an için katılımcıların \%68'i tatile çıkmayı düşünmediklerini ifade etmişlerdir.

Devletin seyahat yasaklarını kaldırması durumunda katılımcıların yaklaşık \%64'ü Temmuz-Ekim dönemi içinde tatile çıkabileceklerini ifade ederken $\% 25^{\prime} \mathrm{i}$ ise en az bir yıl sonra tatil yapmayı düşündüğünü ifade etmiştir. Ayrıca yaklaşık turistlerin \%7'si pandeminin biteceğine emin oldukları zaman tatil yapacaklarını belirtmişlerdir. Her üç katılımcıdan birinin bu yıl tatil yapmayı düşünmedikleri söylenebilir. Geri kalan kısmının mevcut şatlarda dahi tatil yapmayı düşünmeleri turizm işletmeleri için umut verici bir durumdur. Ancak pandemi ile ilgili yaşanacak olumlu veya olumsuz gelişmelerin bu durumu değiştirebileceği tahmin edilmektedir. Ayrıca kişilerin pandemi sonrasında yaşadıkları gelir kayıpları tatil bütçelerinin azalmasına veya tatile bütçe ayıramamalarına sebep olabilir. Dolayısıyla seyahat kısıtlamalarının ortadan kalkması durumunda turizm işletmelerinin önceliği tatile çıkmayı arzulayan turist kitlesi olmalı ve onların ihtiyaç ve isteklerine cevap vermek için çabalamalıdırlar. Tatil bütçesi konusunda daralma yaşayan turistler için, bütçeye uygun tatil paketlerini sunmak turizm hareketlerine katılımı arttırabilir. Yasaklar kalksa bile sağlık riskinden dolayı en az bir yıl tatil yapmama görüşüne sahip olan turistlerin turizm hareketlerine dahil olabilmeleri için salgınla ilgili aşı ve tedavi yöntemlerindeki gelişmelerin etkili olacağı düşünülmektedir. Eğer tedavi ile ilgili olumlu gelişmelerin yaşanması durumunda bu kitle içerisinden de turizm hareketlerine katılım olabilir.

Turistlerin tatil yapabilme şartlarının oluşması durumunda, tatile gitmek isteyecekleri turizm bölgeleri ele alındığında tercihler Ege ve Akdeniz bölgelerine yöneliktir. Üçüncü sırada Marmara Bölgesi yer alırken katılımcıların sadece yaklaşık \%7'si yurtdışına gitmek istediğini ifade etmiştir. Mevcut durumun yarattığı şartlar ele alındığında tatil yeri yurtdışı olan Türk turistlerin önümüzdeki dönemde yurtiçini tercih edecekleri söylenebilir. Ayrıca bu sezon için Türk turistler içerisinde tatil destinasyonu olarak ikamet ettikleri yerlere yakın bölgeleri tercih etme durumları da olabilir. Dolayısıyla nüfus bakımından büyük olan illere yakın tatil destinasyonları açısından bu durum fırsata dönüşebilir.

İmkan dahilinde turistlerin tatillerinde tercih ettikleri konaklama tesisleri ele alındığında turistlerin \%42'si butik tesislerde kalacağını belitmiş, \%21'i de kamp yapabileceklerini belirtmiştir. Yaklaşık $\% 7$ 'si ise yazlık evleri tercih edeceklerini ifade etmişlerdir. Büyük ölçekli otel ve tatil köyünden yana tercih yapacaklarını belirten turist oranı yaklaşık \%28 olarak tespit edilmiştir. Turistlerin sosyal mesafeyi koruma amaçlı bu yıl daha küçük tesislerde ya da tatil yerlerinde vakit geçirebilecekleri beklenen durumlardan bir tanesidir. Bu durum küçük ölçekli konaklama tesisleri için avantaj sağlarken büyük ölçekli konaklama tesisleri için handikap oluşturabilir. Küçük ölçekli konaklama tesislerinin pazarlama iletişimi çabalarında bu duruma dikkat çekmeleri rekabet avantajı yaratabilir. Özellikle tesis içerisinde insanlar arasında mesafelerin korunması ve küçük tesislerin hijyen ortamını sağlamada daha başarılı olabileceği konusunda turistleri ikna etmeleri gerekir. 
Araştırmaya katılan katılımcılara ilk fırsatta tatile çıkma isteklerinin altında yatan sebepler içerisinde en çok rahatlama ve dinlenme ihtiyacı olduğu görülmüştür. Bu sonuç literatürdeki seyahat motivasyonları ile örtüşmektedir (Mehmetoğlu, 2004; Harman vd., 2013; Harman, 2014; Bingöl ve Çakır, 2020). Motivasyonla ilgili araştırmaların çoğunda turistleri tatil yapmaya iten en önemli sebepler arasında zihinsel ve bedensel dinlenme ihtiyacının olduğu ve bu ihtiyaçların giderilmesi ile turistlerin kendilerini yenilenmiş ve baskıdan kurtulmuş hissettiği ifade edilmektedir. Çalışma ve günlük hayatın getirdiği stres ve yorgunluğun yanında pandemi durumunun oluşturduğu gergin ortam ve dönem sonrasında bu çalışmada turistlerin tatil yapma sebeplerinden en önemlisi rahatlama ve dinlenme olarak ortaya çıkması beklenen bir durumdur. Bunların yanında yaz tatili (deniz, kum, güneş) aile ve arkadaşla vakit geçirmek yeni yerler görmek isteyen turistler de bulunmaktadır. Turistlerin rutinden ve stresten uzaklaşmak ve dinlenip rahatlamak istemeleri doğa ve yayla turizmi gibi alternatif turizm türlerine katılımı arttırabilir. Alternatif turizm türlerine yönelik hazırlanacak tatil paketlerine talepte artış olması beklenebilir.

Katılımcıların işletmelerden alması gereken tedbirler içerisinde katılımcıların \%84'ü temizlik ve hijyen beklentisini dile getirmiştir. İşletmelerden genel olarak temizlik ve hijyen beklentisi içinde bulunan turistler özellikle oda, ortak kullanım alanları, havuz, havalandırma ve tuvalet temizliği açısından beklentilerini ifade etmişlerdir. Ayrıca işletme içinde sosyal mesafenin korunmasına yönelik düzenlemeler dile getirilmiş ve işletmelerin tam kapasite ile çalışmamaları yönünde birtakım beklentiler sunulmuştur. Bunların yanında işletmelerden gıda güvenliğine yönelik tedbirler alınması istenmiştir. Ayrıca sağlık taramalarının yapılması, yabancı turist kabul edilmemesi ve havuzların açılmaması yönünde beklentileri olan turistlerde bulunmaktadır. Turistlerin işletmelerden almasını istedikleri tedbirler ile Kültür ve Turizm Bakanlığı' nın turizm işletmelerine yönelik yaptığı tavsiyeler arasında (kapasite düzeni, temastan kaçınma, dezenfeksiyon, ateş ölçümü vb.) büyük benzerlikler bulunmaktadır. Turistlerin pandemiye yönelik bilinç geliştirmesinde ve beklenti oluşturmasında Sağlık Bakanlığı'nın konu ile ilgili yaptı̆̆ı bilgilendirmelerin önemli rol oynadığı söylenebilir. Katılımcıların belirli bir kısmı (\%16) ise pandemiye karşı alınabilecek bir tedbir kesin çözüm olmayacağını düşünmektedir. Bulaşıcılığın tehlike oluşturduğu ve tedbirlerin bulaşıcılık karşısında kesin çözüm olamayacağını düşünen bu grubun pandemi tehlikesi tamamen geçmeden başkaları ile aynı fiziki çevre içerisinde tatil yapmayacakları düşünülmektedir.

Sonuç olarak pandeminin kısa vadede uluslararası turizm hareketlerini keskin bir şekilde olumsuz etkileyeceği tahmin edilen bir durumdur. Ancak turist beklentileri de ele alındığında bazı belirsizliklerin ortadan kalkması durumunda, yurtiçi tatil faaliyetlerinin başlayabileceği söylenebilir. Belirsizlikler içinde pandemiye yönelik tedavilerin ortaya çıkması ve ayrıca işletmelerin alacakları COVID-19 önlemleri özellikle yurtiçi turizm hareketlerinin başlamasını ve gelişmesini sağlayabilir. $\mathrm{Bu}$ yüzden turizm işletmeleri turizm hareketlerinin başlama ihtimaline karşı hazırlıklarını yapmalıdırlar.

Bu çalışmanın birçok çalışma gibi sınırlılıkları mevcuttur. Öncelikle araştırma kolayda örnekleme yöntemi ile çevrimiçi ortamda daha önce tatil satın alan 571 turist ile sınırlanmıştır. Bütün potansiyel turistleri dahil edebilecek farklı örnekleme yöntemleri ile çalışma tekrarlanabilir. Ayrıca COVID-19'a yönelik yaşanabilecek olumlu ve olumsuz gelişmeler doğrultusunda turist beklentilerinde değişme olması mümkündür. Dolayısıyla turist davranışları tahmin edebilmek ve turizm işletmelerine yol göstermek için yaşanabilecek her gelişmeden sonra çalışma tekrarlanmalıdır. 


\section{KAYNAKÇA}

Acar, Y. (2020). Yeni Koronavirüs (COVID-19) Salgını ve Turizm Faaliyetlerine Etkisi. Güncel Turizm Araştırmaları Dergisi, 4(1): 7-21.

A.C.I. (2020). The Impact of COVID-19 On the Airport Business: Preliminary Assessment, ACI Report, 1-25.

Amir, F. A, Mohd, N.I.I. and Toh, P.S. (2015). Sustainable Tourist Environment: Perception of International Women Travelers on Safety and Security İn Kuala Lumpur. Procedia Social and Behavioral Sciences, (168): 123-13.

Aslan, R. (2020). Tarihten Günümüze Epidemiler, Pandemiler ve COVID-19. Göller Bölgesi Aylık Ekonomi ve Kültür Dergisi Ayrıntı, 8(85): 35-41.

Atay, L. (2020). KOVID-19 Salgını ve Turizme Etkileri. Seyahat ve Otel İşletmeciliği Dergisi, 17(1): 168172.

Bingöl, S. ve Çakır, P. G. Van Gölü Kıyılarını Ziyaret Eden Kırsal Turistlerin Özellikleri. Gastroia: Journal of Gastronomy and Travel Research, 4(1): 106-120.

Cui, F., Liu, Y., Chang, Y., Duan, J. and Li, J. (2016). An Overview of Tourism Risk Perception. Natural Hazards, 82: 643-658.

Dolnicar, S. (2007). Crises That Scare Tourists: Investigating Tourists' Travel-Related Concerns, In B. Prideaux, B. Laws and K. Chon (Eds.): Managing Tourism Crises (pp. 98-109) London: CABI Publishing.

Fendoğlu, E. ve Gökçe, E. C. (2019). Türkiye'nin Turizm Geliri Serisinin Durağanlığı: Fourier KPSS Durağanlık Testi. Ekonometri ve İstatistik Dergisi, (31): 17-28.

Glaesser, D. (2003). Crisis Management in the Tourism Industry. Burlington: Butterworth-Heinemann.

Göçen, S., Yırık, Ş., ve Yilmaz, Y. (2011). Türkiye'de Krizler ve Krizlerin Turizm Sektörüne Etkileri. Suleyman Demirel University Journal of Faculty of Economics and Administrative Sciences, 16(2): 493-509.

Gökçe, Orhan. (2006). İçerik Analizi: Kuramsal ve Pratik Bilgiler. (1.Basım) Ankara: Siyasal Kitabevi.

Grössling, S., Scott, D. and Hall, C. M. (2020). Pandemics, Tourism and Global Change: A Rapid Assessment Of COVID-19. Journal of Sustainable Tourism, 1-20. (Online) https://www.tandfonline.com/doi/pdf/10.1080/09669582.2020.1758708 (Erişim Tarihi:11.05.2020).

Gulzar, A., Khan, T. A. and Hamid, W. (2019). Analysing the Economic Impact of Tourism in Kashmir. World Affairs: The Journal of International Issues, 23(3): 108-117.

Harman, S., Çakıcı, A. C. ve Akatay, A. (2013). İstanbul'a Gelen Sırt çantalı Turistlerin Seyahat Motivasyonları Üzerine Bir Araştırma. Selçuk Üniversitesi İktisadi ve İdari Bilimler Fakültesi, Sosyal ve Ekonomik Araştırmalar Dergisi, 13(25): 267-300. 
Harman, S. (2014). Bağımsız Seyahat Eden Yerli Gezginlerin Seyahat Motivasyonları Üzerine Bir Araştırma. Uluslararası Yönetim İktisat ve İşletme Dergisi, 10(21): 107-128.

Hoque, A., Shikha, F. A., Hasanat, M. W., Arif, I. and Hamid, A. B. A. (2020). The Effect of Coronavirus (COVID-19) in the Tourism Industry in China. Asian Journal of Multidisciplinary Studies, 3(1): 52-58.

https://www.bbc.com/turkce/haberler-turkiye-51887341 (Erişim Tarihi:10.05.2020).

https://www.hurriyet.com.tr/dunya/dunya-iceri-cin-disari-41477096 (Erişim Tarihi: 12.05.2020).

https://www.tursab.org.tr/istatistikler (Erişim Tarihi: 12.05.2020).

https://www.who.int/emergencies/diseases/novel-coronavirus-2019 (Erişim Tarihi:15.05.2020).

I.A.T.A. (2020). Covid-19 Updated Impact Assessment, IATA Press, 1-9.

Ivanov, S. and Webster, C. (2007). Measuring the Impact of Tourism on Economic Growth. Tourism Economics, 13(3): 379-388.

İbiş, S. (2020). Covıd-19 Salgınının Seyahat Acentaları Üzerine Etkisi. Safran Kültür ve Turizm Araştırmaları Dergisi, 3(1): 85-98.

Jonas, A., Mansfeld, Y., Paz, S. and Potasman, I. (2011). Determinants of Health Risk Perception among Low-Risk-Taking Tourists Traveling to Developing Countries. Journal of Travel Research, 50(1): 87-99.

Karadeveci, Z.B. (2004). Kriz Ortamında Turizm İşletmelerinde Risk Yönetimi ve Finansal Kararlar, Yayınlanmamış Yüksek Lisans Tezi, Dokuz Eylül Üniversitesi, İzmir.

Kozak, M., Crotts JC, Law R. (2007). The Impact of the Perception of Risk on International Travelers. International Journal Touism Research, 9(4): 233-242.

Li, P., Feng, W., Xue, C., Tian, R. and Wang, S. (2017). Spatiotemporal Variability of Contaminants in Lake Water and Their Risks to Human Health: A Case Study of The Shahu Lake Tourist Area, Northwest China. Exposure and Health, 9(3): 213-225.

Lohmann, M. (2004). New Demand Factors in Tourism. In European Tourism. Budapest: Presentation at the European Tourism forum, 14(3): 345-351.

Mayer, M., Müller, M., Woltering, M., Arnegger, J. and Job, H. (2010). The Economic Impact of Tourism in Six German National Parks. Landscape and Urban Planning, 97(2): 73-82.

McKibbin, W. J. and Fernando, R. (2020). The Global Macroeconomic Impacts of COVID-19: Seven Scenarios. https://papers.ssrn.com/sol3/papers.cfm?abstract_id=3547729 (Erişim Tarihi 10.05.2020).

Mehmetoğlu, M. (2004). A Typology of Tourists from a Different Angle. International Journal of Hospitality and Tourism Administration, 5(3): 69-90.

Pratt, S. (2015). The Economic Impact of Tourism in SIDS. Annals of Tourism Research, 52: 148-160. 
Ünlüönen, K. ve Çeti, B. (2019). Salgın Hastalıklar Sebebiyle Oluşan Krizlerin Turizm Sektörü Üzerindeki Etkisinin Değerlendirilmesi. Ankara Hacı Bayram Veli Üniversitesi Turizm Fakültesi Dergisi, 22(2): 109-128.

Wilson, M.E. and Chen, L. H. (2020). Travelers Give Wings to Novel Coronavirus (2019-Ncov). Journal of Travel Medicine, 27(2): 1-3.

Yang, Y., Hongru, Z. and Xiang, C. (2020). Coronavirus Pandemic and Tourism: Dynamic Stochastic General Equilibrium Modeling of İnfectious Disease Outbreak. Annals of Tourism Research, 81(3): 1-2.

Zurub, H., Ionescu, A. and Constantin, V. D. (2015). Measuring the Economic Impact of Tourism in European Emerging Markets. Procedia Economics and Finance, 32(2015): 95-102. 